\title{
REVENUE ELASTICITY OF THE MAIN FEDERAL TAXES IN MEXICO*
}

\author{
Felipe J. Fonseca ** \\ DANiel VentosA-SANTAULÀria ${ }^{* * *}$
}

\begin{abstract}
An inelastic tax system increases the uncertainty associated with tax revenue collection. This results in continuous short-term adjustments to maintain the stability of tax collection. In this paper, we estimate the revenue elasticity of the principal taxes in Mexico, finding a much greater elasticity than that found in previous studies. A cointegration model between the revenue and taxes is used which satisfies strong exogeneity, providing a basis for congruent and reliable projections. Using this model, the tax revenue projected for 2011 is much lower than the estimates prepared by Mexico's federal government.
\end{abstract}

JEL clasification: C22, E62, H24.

Keywords: Federal taxes, long-term revenue elasticity, cointegration, strong exogeneity, forecasts

\section{INTRODUCTION}

Having a tax system in which the revenue elasticity of taxes is greater than or equal to one is of considerable importance for public finance (see for example Groves and Khan, 1952). If it is elastic, tax collection evolves with growth in national income, reducing the uncertainty associated with tax revenue. If, on the contrary, the tax system is inelastic to income, frequent tax rate changes are required in order to maintain collection at steady levels in the short term (Capistrán, 1999). This has a negative impact on resource allocation and distribution in an economy.

Likewise, the sensitivity of tax collection to income is valuable information for the government, both in terms of planning and formulating public spending and monitoring tax collection (Kustepeli and Sapci, 2006). In the case of Mexico, this aspect is explicitly considered in the Revenue Law Initiative (Iniciativa de Ley de Ingresos, or ILIF) which Treasury

* The authors are grateful for comments provided by an anonymous referee and by editor Raimundo Soto. Part of this study was carried out during Daniel Ventosa-Santaulària's stay at the Center of Research in Econometric Analysis of Time Series (CREATES) at the Universidad of Aarhus, Denmark. He would like to thank Niels Haldrup and the members of CREATES for their hospitality and the Danish National Research Foundation (Denmark) and the National Council for Science and Technology (Mexico) for their financial support.

** University of Guadalajara, Mexico. Email: fjfonseca82@gmail.com

*** Corresponding author: University of Guanajuato, Mexico. Email: daniel@ventosa-santaularia.com 
authorities submit to Congress each year. This means that, when calculating tax revenue collection, the real long-term revenue elasticity of each tax will be considered in addition to the macroeconomic context expected for the period covered by the forecast.

In this context, the main objective of this paper is to calculate the revenue elasticity of Mexico's main tax revenues, which are the income tax (Impuesto sobre la Renta, or ISR) and the value-added tax (Impuesto al Valor Agregado, or IVA). Only the elasticity of these two taxes is studied because they account for practically all (approximately $90 \%$, according to information from the Treasury Secretariat) of nonpetroleum tax revenue collection.

The results obtained from analysis of time series (i) confirm the existence of evidence of a long-term relationship between taxes and national income, and (ii) indicate that this ratio is elastic. The revenue elasticity obtained for the IVA is 2.03 , while for the ISR the revenue elasticity obtained was 2.16 .

Recent literature contains various calculations of such elasticities, in particular those performed by Cárdenas et al. (2008) and those of the Public Finance Research Center (Centro de Estudios de las Finanzas Públicas del Congreso de la Unión) ${ }^{1}$ in 2009 (which we refer to as CEFP, 2009a). In comparison to those studies, this one includes several improvements and extensions, including the incorporation of the tax rate in order to control for this variable in studying the taxrevenue relationship.

Also notable is the use of more modern econometric tools which are capable of effectively controlling the presence of structural breaks and defining their location in an endogenous way. Likewise, Johansen's (1988) methodology, the standard process in modern macro-econometrics, is used to calculate the relationship between the variables. Among the most interesting results is evidence of strong exogeneity of the parameter associated to the explanatory variable of the specification (revenue), which can be considered a useful and valid instrument for preparing tax-collection forecasts.

At the same time, the ability to develop forecasts based on the autoregressive vector with an error correction mechanism (vector error correction, or VEC) is verified and this is compared to the official forecasts provided by the Treasury Secretariat. 
Table 1. Federal government revenue as a percentage of GDP (2000-2010)

\begin{tabular}{lrrrrrrrrrrrr}
\hline Item & $\mathbf{2 0 0 0}$ & $\mathbf{2 0 0 1}$ & $\mathbf{2 0 0 2}$ & $\mathbf{2 0 0 3}$ & $\mathbf{2 0 0 4}$ & $\mathbf{2 0 0 5}$ & $\mathbf{2 0 0 6}$ & $\mathbf{2 0 0 7}$ & $\mathbf{2 0 0 8}$ & $\mathbf{2 0 0 9}$ & $\mathbf{2 0 1 0}$ \\
Total & $\mathbf{1 8 . 5}$ & $\mathbf{1 9 . 2}$ & $\mathbf{2 0 . 4}$ & $\mathbf{2 1 . 2}$ & $\mathbf{2 0 . 7}$ & $\mathbf{2 1 . 1}$ & $\mathbf{2 1 . 9}$ & $\mathbf{2 2 . 0}$ & $\mathbf{2 3 . 5}$ & $\mathbf{2 3 . 7}$ & $\mathbf{2 2 . 6}$ \\
Petroleum & $\mathbf{6 . 1}$ & $\mathbf{5 . 8}$ & $\mathbf{6 . 0}$ & $\mathbf{7 . 1}$ & $\mathbf{7 . 4}$ & $\mathbf{7 . 9}$ & $\mathbf{8 . 3}$ & $\mathbf{7 . 8}$ & $\mathbf{8 . 7}$ & $\mathbf{7 . 4}$ & $\mathbf{7 . 4}$ \\
Non-petroleum & $\mathbf{1 2 . 5}$ & $\mathbf{1 3 . 3}$ & $\mathbf{1 4 . 3}$ & $\mathbf{1 4 . 1}$ & $\mathbf{1 3 . 2}$ & $\mathbf{1 3 . 2}$ & $\mathbf{1 3 . 6}$ & $\mathbf{1 4 . 2}$ & $\mathbf{1 4 . 8}$ & $\mathbf{1 6 . 3}$ & $\mathbf{1 5 . 2}$ \\
$\quad$ Tax & 8.1 & 8.6 & 9.0 & 9.0 & 8.4 & 8.6 & 9.0 & 9.3 & 9.9 & 9.5 & 10.0 \\
$\quad$ - ISR total & 4.1 & 4.3 & 4.7 & 4.5 & 4.0 & 4.2 & 4.3 & 4.7 & 5.1 & 5.0 & 5.2 \\
$\quad$ - IVA & 3.0 & 3.1 & 3.2 & 3.4 & 3.3 & 3.5 & 3.7 & 3.6 & 3.8 & 3.4 & 3.9 \\
Total & & & & & & & & & & & \\
$\quad$ Tax & $\mathbf{1 8 . 5}$ & $\mathbf{1 9 . 2}$ & $\mathbf{2 0 . 4}$ & $\mathbf{2 1 . 2}$ & $\mathbf{2 0 . 7}$ & $\mathbf{2 1 . 1}$ & $\mathbf{2 1 . 9}$ & $\mathbf{2 2 . 0}$ & $\mathbf{2 3 . 5}$ & $\mathbf{2 3 . 7}$ & $\mathbf{2 2 . 6}$ \\
$\quad$ Non-tax & 9.2 & 9.9 & 10.7 & 10.1 & 9.0 & 8.8 & 8.6 & 8.9 & 8.2 & 9.5 & 9.6 \\
& 9.4 & 9.3 & 9.7 & 11.0 & 11.7 & 12.3 & 13.3 & 13.1 & 15.3 & 14.2 & 13.0 \\
Source: Treasury and Public Credit Secretariat of Mexico (SHCP). & & & & & \\
\hline
\end{tabular}

This paper is organized as follows: Section 2 contains a brief description of the structure of federal revenues in Mexico, emphasizing the importance of the taxes examined in this paper within this structure. Section 3 contains an analysis of cointegration as well as a discussion of the econometric results obtained, the preparation of forecasts, and a comparison of these forecasts with the official ones. Finally, the main conclusions of the study are presented in Section 4.

\section{THE ISR AND IVA IN THE STRUCTURE OF THE MeXiCAN TAX SYSTEM}

Mexico has the lowest tax collection rate among OECD countries (OECD, 2010). According to OECD data, the average collection rate among its member countries is $24.7 \%$ of GDP, but in Mexico this indicator is around $10 \%$. Another important characteristic of the Mexican fiscal system is that it is heavily dependent on resources from taxes on petroleum activities, which account for one-third of total federal government revenue (CEFP, 2010). Table 2 shows how the structure of total federal government revenue has evolved as a percentage of GDP from 2000 to 2010, displaying the aforementioned characteristics as well as the particular weight of collection of total ISR ${ }^{2}$ and IVA, with average values between $4-5$ and $3-4 \%$ of GDP, respectively. 
Regarding the percentage structure of total federal government revenues, Table 2 shows that petroleum revenues (in its various forms, rights, uses, etc.) have represented one-third of total revenues, as previously mentioned. With respect to non-petroleum revenue, in the tax category the overall collection of the two taxes studied represents just over half of the federal government's non-petroleum revenue.

Table 2. Percentage structure of total federal government revenues

(2000-2010)

\begin{tabular}{lrrrrrrrrrrr}
\hline Item & $\mathbf{2 0 0 0}$ & $\mathbf{2 0 0 1}$ & $\mathbf{2 0 0 2}$ & $\mathbf{2 0 0 3}$ & $\mathbf{2 0 0 4}$ & $\mathbf{2 0 0 5}$ & $\mathbf{2 0 0 6}$ & $\mathbf{2 0 0 7}$ & $\mathbf{2 0 0 8}$ & $\mathbf{2 0 0 9}$ & $\mathbf{2 0 1 0}$ \\
Total & $\mathbf{1 0 0 . 0}$ & $\mathbf{1 0 0 . 0}$ & $\mathbf{1 0 0 . 0}$ & $\mathbf{1 0 0 . 0}$ & $\mathbf{1 0 0 . 0}$ & $\mathbf{1 0 0 . 0}$ & $\mathbf{1 0 0 . 0}$ & $\mathbf{1 0 0 . 0}$ & $\mathbf{1 0 0 . 0}$ & $\mathbf{1 0 0 . 0}$ & $\mathbf{1 0 0 . 0}$ \\
Petroleum & $\mathbf{3 2 . 7}$ & $\mathbf{3 0 . 4}$ & $\mathbf{2 9 . 6}$ & $\mathbf{3 3 . 3}$ & $\mathbf{3 6 . 0}$ & $\mathbf{3 7 . 3}$ & $\mathbf{3 8 . 0}$ & $\mathbf{3 5 . 4}$ & $\mathbf{3 6 . 9}$ & $\mathbf{3 1 . 0}$ & $\mathbf{3 2 . 9}$ \\
Non-petroleum & $\mathbf{6 7 . 3}$ & $\mathbf{6 9 . 6}$ & $\mathbf{7 0 . 4}$ & $\mathbf{6 6 . 7}$ & $\mathbf{6 4 . 0}$ & $\mathbf{6 2 . 7}$ & 62.0 & $\mathbf{6 4 . 6}$ & $\mathbf{6 3 . 1}$ & $\mathbf{6 9 . 0}$ & $\mathbf{6 7 . 1}$ \\
Federal Gov. & 49.5 & 51.6 & 52.6 & 48.5 & 46.5 & 44.7 & 44.8 & 48.5 & 47.5 & 53.5 & 50.4 \\
$\quad$ Tax & 43.7 & 44.7 & 44.4 & 42.4 & 40.5 & 40.7 & 41.1 & 42.1 & 42.2 & 39.9 & 44.4 \\
- ISR-IETU-IDE & 22.0 & 22.5 & 23.0 & 21.1 & 19.5 & 19.7 & 19.8 & 21.2 & 21.9 & 21.1 & 23.0 \\
- IVA & 16.1 & 16.4 & 15.7 & 15.9 & 16.1 & 16.3 & 16.8 & 16.5 & 16.0 & 14.5 & 17.0 \\
- Production and services & 1.3 & 1.8 & 1.7 & 1.9 & 1.8 & 1.8 & 1.6 & 1.7 & 1.7 & 1.7 & 2.0 \\
- Imports & 2.8 & 2.3 & 2.0 & 1.7 & 1.7 & 1.4 & 1.4 & 1.3 & 1.3 & 1.1 & 0.8 \\
- Other taxes & 1.6 & 1.7 & 2.0 & 1.9 & 1.4 & 1.5 & 1.5 & 1.5 & 1.4 & 1.6 & 1.5 \\
$\quad$ Non-tax & 5.8 & 7.0 & 8.2 & 6.0 & 6.0 & 4.0 & 3.7 & 6.4 & 5.2 & 13.6 & 6.0
\end{tabular}

Source: Treasury and Public Credit Secretariat.

Note: IDE is the Tax on Cash Deposits; IETU is the Uniform Rate Business Tax.

Therefore, observing the behavior of effective tax rates is quite relevant. ${ }^{3}$ Such rates reflect marginal growth as a proportion of the corresponding basis, which is sustained somewhat by collection efforts over the last 20 years, but they also reveal that Mexico's collection level is low, especially when compared to OECD member countries.

On the other hand, an analysis of the tax revenue composition clearly shows that the total ISR and IVA together constitute almost $90 \%$ of revenues, while the remaining $10 \%$ is distributed between the tax on production and services (non-petroleum), the import tax and others (see Table 3).

3. Figures for the effective rates of the taxes studied here were calculated using CEFP (2009b and 2010) and are based on the work of Antón-Sarabia (2005). As the latter study explains, the effective tax rate takes into consideration each collection measurement expressed as a fraction of its own basis: consumption for the IVA and individuals' salaries for the ISR. It is worth noting that the effective tax rates cannot be considered exogenous instruments in the econometric analysis given that, due to their construction, they would have to be considered endogenous to the system. 
Table 3. Percentage structure of tax revenues (2000-2010)

\begin{tabular}{lrrrrrrrrrrr}
\hline Item & $\mathbf{2 0 0 0}$ & $\mathbf{2 0 0 1}$ & $\mathbf{2 0 0 2}$ & $\mathbf{2 0 0 3}$ & $\mathbf{2 0 0 4}$ & $\mathbf{2 0 0 5}$ & $\mathbf{2 0 0 6}$ & $\mathbf{2 0 0 7}$ & $\mathbf{2 0 0 8}$ & $\mathbf{2 0 0 9}$ & $\mathbf{2 0 1 0}$ \\
ISR total & $\mathbf{5 0 . 2}$ & $\mathbf{5 0 . 3}$ & $\mathbf{5 1 . 7}$ & $\mathbf{4 9 . 6}$ & $\mathbf{4 8 . 2}$ & $\mathbf{4 8 . 5}$ & 48.1 & $\mathbf{5 0 . 3}$ & $\mathbf{5 1 . 9}$ & $\mathbf{5 2 . 9}$ & $\mathbf{5 1 . 7}$ \\
- ISR & 50.2 & 50.3 & 51.7 & 49.6 & 48.2 & 48.5 & 48.1 & 50.3 & 46.6 & 47.5 & 47.7 \\
- IETU & n.a. & n.a. & n.a. & n.a. & n.a. & n.a. & n.a. & 0.0 & 3.9 & 4.0 & 3.4 \\
- IDE & n.a. & n.a. & n.a. & n.a. & n.a. & n.a. & n.a. & 0.0 & 1.5 & 1.4 & 0.6 \\
IVA & $\mathbf{3 6 . 8}$ & $\mathbf{3 6 . 7}$ & $\mathbf{3 5 . 5}$ & $\mathbf{3 7 . 5}$ & $\mathbf{3 9 . 8}$ & 40.2 & 40.9 & 39.1 & $\mathbf{3 7 . 9}$ & $\mathbf{3 6 . 2}$ & $\mathbf{3 8 . 4}$ \\
Production and services & 3.0 & 4.1 & 3.9 & 4.4 & 4.5 & 4.3 & 4.0 & 4.0 & 4.1 & 4.2 & 4.6 \\
Imports & 6.4 & 5.1 & 4.4 & 4.0 & 4.1 & 3.4 & 3.4 & 3.1 & 3.0 & 2.7 & 1.9 \\
Other taxes & 3.7 & 3.8 & 4.5 & 4.5 & 3.5 & 3.6 & 3.6 & 3.6 & 3.2 & 4.0 & 3.4 \\
ISR total and IVA & $\mathbf{8 7 . 0}$ & $\mathbf{8 7 . 0}$ & $\mathbf{8 7 . 1}$ & $\mathbf{8 7 . 1}$ & $\mathbf{8 7 . 9}$ & $\mathbf{8 8 . 6}$ & $\mathbf{8 9 . 0}$ & $\mathbf{8 9 . 4}$ & $\mathbf{8 9 . 7}$ & $\mathbf{8 9 . 1}$ & $\mathbf{9 0 . 1}$ \\
& & & & & & & & & & & \\
Source: Treasury and Public Credit Secretariat. & & & & & & & & \\
Note: n.a. $=$ not applicable. & & & & & & & & & & &
\end{tabular}

Figure 1. Tax rate of the IVA

(Quarterly series)

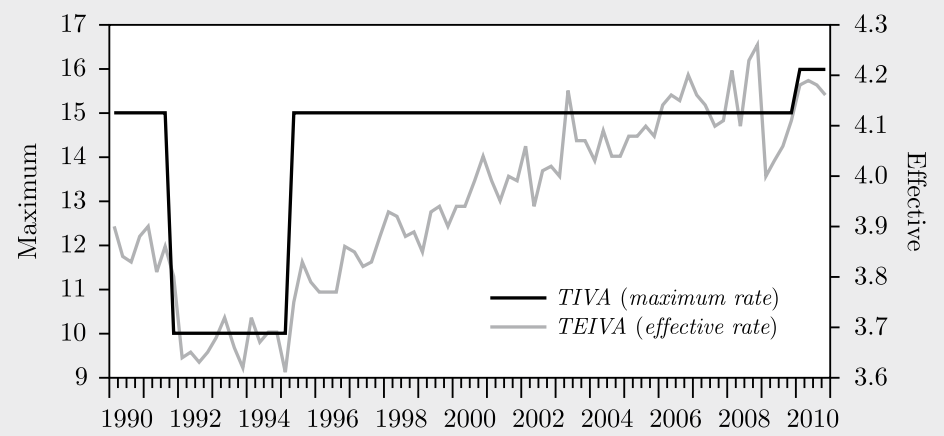

Source: Treasury Secretariat and authors' calculations based on Antón-Sarabia (2005) and CEFP (2009b).

\section{Figure 2. Tax rate of the ISR}

\section{(Annual series)}

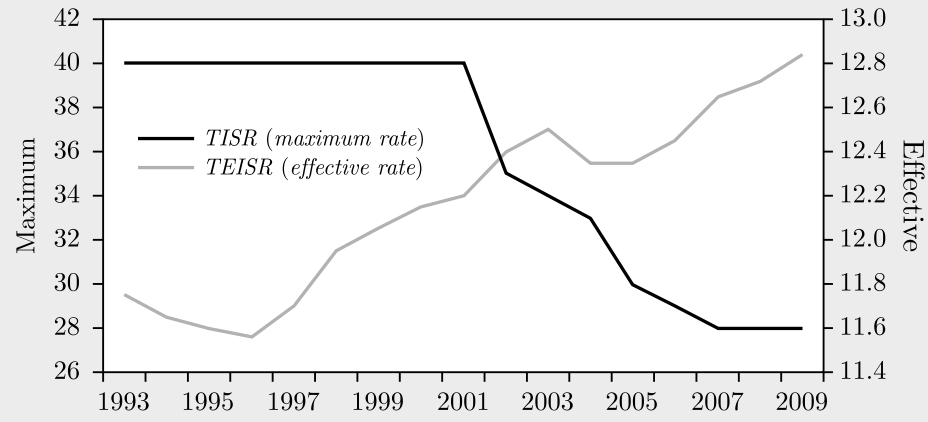

Source: Treasury Secretariat and authors' calculations based on Antón-Sarabia (2005) and CEFP (2010). 


\section{TIME SERIES ANALYSIS}

The basic series for the analysis are collection data of the ISR (excluding the IDE and the IETU) and the IVA, as published on the web page of the Treasury Secretariat ${ }^{4}$ and the web page of the National Institute for Statistics and Geography (Instituto Nacional de Estadistica y Geografía, or INEGI), ${ }^{5}$, which publishes the GDP. Regarding the IVA, there are three special treatments (border rate, exempt goods and services, and zero rate) and as a result the nominal rate differs from the average effective rate. The same occurs with the ISR, which underwent a significant reform in 2001. This reform reduced the annual rates by one percentage point for legal entities, which represent a significant percentage of collection along with individuals (the rate used in this study). Although it would be convenient to use the average effective rate and not the nominal rate, this is not feasible for various reasons. In reference to the IVA, and because this study focuses on time series, such questions could eventually be modeled by using dummy or proxy variables. Nevertheless, the modeling would be too ad hoc, reducing the validity and interest of the model.

For the ISR, data are only available from 1993 to 2009 and solely on an annual basis. Its use in this study would require quarterizing the annual data. We consider that the available methods (e.g., Chow and Lin) produce a serious detriment to the statistical quality of the series and moreover, do not resolve the problem of obtaining the effective rate data for 2010, so the treatment of the IVA and the ISR would be very unequal.

Figures 3 and 4 show how these variables have evolved in the period encompassing the first quarter of 1990 through the fourth quarter of 2010, all in millions of constant pesos (base year 2003).

The sample used in this study includes observations from 1990 to 2010, since 1990 is the first year for which the Treasury Secretariat has published information on the collection of the taxes studied. In addition, only information from 1990 and later is taken into consideration in the ILIF projections. In order to ensure that the results obtained here are comparable with those of the Treasury Secretariat, the same sample period will be used.

4. Available at http://www.apartados.hacienda.gob.mx/estadisticas_oportunas/esp/index.html

5. Available at http://dgcnesyp.inegi.org.mx/cgi-win/bdieintsi.exe/NIVA1001200010\#ARBOL 
Figure 3. ISR collection and GDP

(Millions of constant pesos, base year 2003)

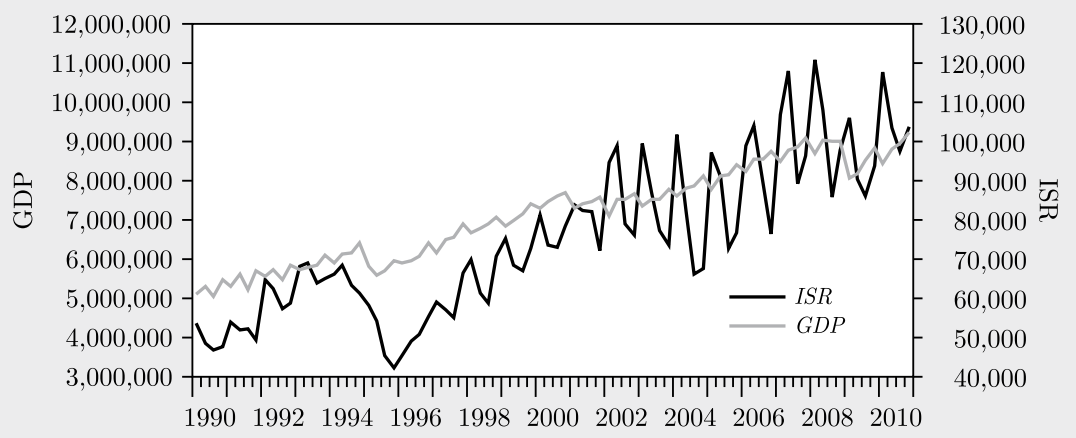

Source: Prepared by the authors using data from INEGI and the Treasury Secretariat.

\section{Figure 4. IVA Collection and GDP}

\section{(Millions of constant pesos, base year 2003)}

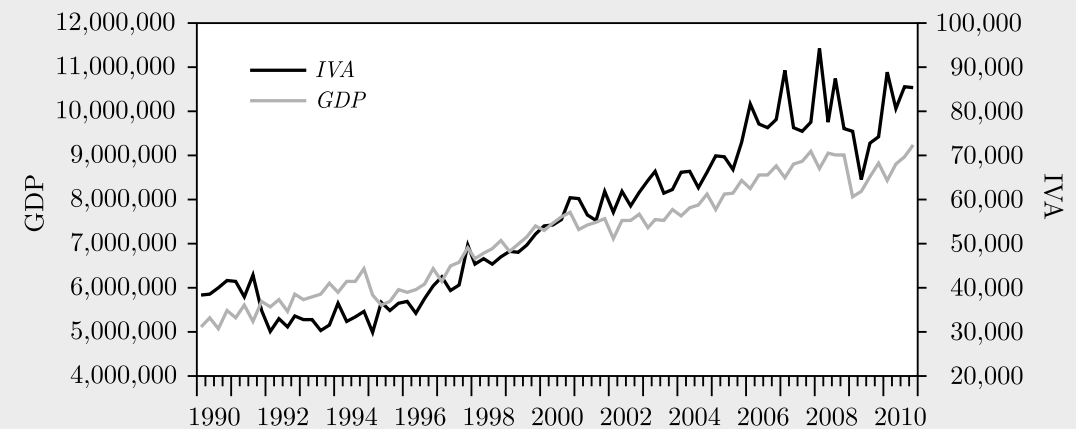

Source: Prepared by the authors using data from INEGI and the Treasury Secretariat.

With regard to the evolution of the variables, it is evident is that the collection of both taxes and the GDP follow a common trend, in the words of Stock and Watson (1988). Therefore in principle it can be conjectured from the simple graphic analysis that it would be possible to calculate the long-term relationships (cointegration) between them. This is formally proven by the tests designed for this purpose. Before discussing the results of the econometric analysis, it is important to 
point out that the IVA and ISR series consider a one-month lag in collection, under the premise that the tax generated in a particular period is actually paid in to the Treasury the following month. Thus, the first quarter of the year is made up of December-January-February, unlike the typical classification of January-February-March, and so on with the other quarters.

\subsection{Series' order of integration}

A typical cointegration analysis requires that the variables to be used be first-order integrated. Thus, first an analysis is done of the series' order of integration. The following table shows the results of different unit root tests applied to the logarithms of the variables in levels and deseasonalized. ${ }^{6}$

Continuing with the analysis, it is worth mentioning that in the auxiliary equations of the ADF, KPSS, DF-GLS and Phillips-Perron tests, only the intercept is included. The objective is to be able to prove the presence of the unit root in the variables while controlling for the possible presence of a deterministic trend. ${ }^{7}$ With respect to the presence of a structural change in the series (which could influence the unit root tests), the Kapetanios (2005) and VentosaSantaulària and Gómez-Zaldívar (2010) (hereafter VSGZ) tests are also carried out. The first test is a generalization of that proposed by Zivot and Andrews (1992); under the null hypothesis, the variable behaves like a unit root while under the alternative, it behaves like a trend stationary process with up to 5 structural breaks. This test does not take into account the possibility of structural breaks under $H_{0}$, so we apply the VSGZ test, which is precisely based on the evidence of unit root and draws inference about the presence of a drift and a possible break in it. ${ }^{8}$ What is sought is the best possible characterization of the series and to obtain broad and abundant evidence of the stochastic trends.

As can be seen in Table 4, the results obtained show clear evidence of the existence of a unit root. This is supported by the Kapetanios test,

6. The series were seasonally adjusted using the X12 ARIMA package.

7. This is because when evidence is not found to reject the unit root null hypothesis, said intercept becomes a linear deterministic trend. In that case (that is, under the null hypothesis), including a deterministic trend in addition to the intercept implies the existence of a quadratic deterministic trend.

8. The number of lags in all the tests (in order to control for autocorrelation and thus prevent distortions in their levels) was determined based on the Schwarz information criterion. 
which contemplates up to two possible breaks. Likewise, the VSGZ test indicates that only the ISR has no trend, unlike the GDP and the IVA; nevertheless, neither of the latter two experiences a break in this trend. In any case, the tests indicate that the three series of interest (IVA, ISR and GDP) have a unit root. Once the order of integration of the variables is verified, we proceed to address the modeling strategy to be used for the calculations.

\section{Table 4. Results of applying the unit root tests}

\begin{tabular}{|c|c|c|c|}
\hline Variable test & GDP & IVA & ISR \\
\hline $\mathrm{ADF}$ & $-1.07^{\dagger}$ & $-0.16^{\dagger}$ & $-0.98^{\dagger}$ \\
\hline KPSS & $1.13^{\dagger}$ & $1.07^{\dagger}$ & $1.15^{\dagger}$ \\
\hline GF-GSL & $1.09^{\dagger}$ & $-0.13^{\dagger}$ & $-0.16^{\dagger}$ \\
\hline Phillips-Perron & $-1.18^{\dagger}$ & $-0.31^{\dagger}$ & $-0.87^{\dagger}$ \\
\hline \multicolumn{4}{|c|}{ Tests with endogenous structural break } \\
\hline Kapetanios $^{\mathrm{a}}(2005)$ & $-4.99^{\dagger}$ & $-5.49^{\dagger}$ & $-5.43^{\dagger}$ \\
\hline VSGZ $^{\mathrm{b}}(2010)$ & $\begin{array}{c}0.97^{* * *} \\
\text { (no evidence } \\
\text { of break) }\end{array}$ & $\begin{array}{c}0.94^{* *} \\
\text { (no evidence } \\
\text { of break) }\end{array}$ & $\begin{array}{c}0.82^{\dagger} \\
\text { (search for breaks } \\
\text { not applicable) }\end{array}$ \\
\hline
\end{tabular}

\subsection{Modeling strategy}

To calculate the long-term relationship between the variables, first the hypothesis of a cointegration vector with structural break is proven with the Gregory and Hansen test (1996), hereafter called GH. This is done in order to correctly specify said relationship. This test enables one to discard or consider that the cointegration ratio is stable or experiences structural breaks throughout the sample period studied. ${ }^{9}$ The GH test is an extension of the Engle and Granger (1987) test and is designed to identify a possible structural break in the cointegration relationship between two or more variables. Table 5 shows the result of applying the $\mathrm{GH}$ test to the long-run equations.

9. Under the null hypothesis of this test, non cointegration is assumed given the alternative, which is that the variables have a long-term relationship subject to a break. This break is determined endogenously. 
Table 5. Results of the GH cointegration test with change of regime

\begin{tabular}{|c|c|c|c|}
\hline & $\begin{array}{l}\text { Model 2: } \\
\text { Change of level } \\
\text { (C) }\end{array}$ & $\begin{array}{l}\text { Model } 3 \\
\text { Change of level with trend } \\
(\mathbf{C} / \mathbf{T})\end{array}$ & $\begin{array}{l}\text { Model } 4 \\
\text { Change of regime } \\
(\mathrm{C} / \mathrm{S})\end{array}$ \\
\hline ISR & $\begin{array}{c}-3.14^{\dagger} \\
(1994: 2)\end{array}$ & $\begin{array}{c}-3.07^{\dagger} \\
(1994: 2)\end{array}$ & $\begin{array}{c}-3.33^{\dagger} \\
(1994: 2)\end{array}$ \\
\hline IVA & $\begin{array}{c}-3.78^{\dagger} \\
(1992: 3)\end{array}$ & $\begin{array}{c}-3.46^{\dagger} \\
(1992: 3)\end{array}$ & $\begin{array}{c}-3.50^{\dagger} \\
(1994: 1)\end{array}$ \\
\hline Critical values & $\begin{array}{cc}1 \% & -5.13 \\
2.5 \% & -4.83 \\
5 \% & -4.61 \\
10 \% & -4.34\end{array}$ & $\begin{array}{cc}1 \% & -5.45 \\
2.5 \% & -5.21 \\
5 \% & -4.99 \\
10 \% & -4.72\end{array}$ & $\begin{array}{cc}1 \% & -5.47 \\
2.5 \% & -5.19 \\
5 \% & -4.95 \\
10 \% & -4.68\end{array}$ \\
\hline \multicolumn{4}{|c|}{$\begin{array}{l}\text { Note: Critical values obtained from Gregory-Hansen }(1996, \mathrm{p} .109) \text { for the case of two variables } \\
\text { - with } m=1 \text {, where } m \text { is the number of regressors - based on the ADF statistic. } \\
\dagger \text { Indicates the acceptance of the null hypothesis - no cointegration - at } 1 \% \text { significance. }\end{array}$} \\
\hline
\end{tabular}

As can be seen, the null hypothesis of non-cointegration is not ruled out in any of the three specifications considered by GH. Thus we proceed to prove the existence of a cointegration relationship between the variables without breaks, based on the Johansen test. ${ }^{10}$ This test includes under the null hypothesis a cointegration vector between the revenue and the tax and is controlled for three variables which are exogenous to the latter. For both relationships, we control for a possible structural break starting in 1994 (the year in which the crisis in Mexico began) ${ }^{11}$ and during the crisis of 2008-2009. Likewise, both for the IVA and the ISR, we include the respective federal tax rate: The maximum rate - currently $16 \%$ - for the former and the maximum rate which is applied to individuals - currently $30 \%$ - for the latter. The results appear in Tables 6 and 7 .

10. The order of the VEC was chosen through optimization of the information criteria of Akaike, Schwarz and Hannan-Quinn. See Appendix A. It is worth emphasizing that the VEC calculations were done with the GRETL software package, the code of which is available at

http://dl.dropbox.com/u/1307356/Arxius\%20en\%20la\%20web/LAJE/LAJE\%20gretl.gdt

11. It should be mentioned that the inclusion of this change is supported by the results of the GH test, which in its full structural change version (see Model 4, "regime shift," last column of Table 5) detects a possible break starting in 1994 in the relationship of both taxes to the GDP. Because the null hypothesis could not be ruled out, a cointegration vector without changes was modeled, but the break was included as a variable exogenous to the vector. Regarding the 2008-2009 crisis, its effect on the relationship is hard to identify as it is practically at the end of the sample, which represents a technical obstacle in carrying out the break tests. Nevertheless, its inclusion in the VEC as an exogenous variable assumed a significantly better adjustment. 
Table 6. Results of the Johansen cointegration test for the IVA

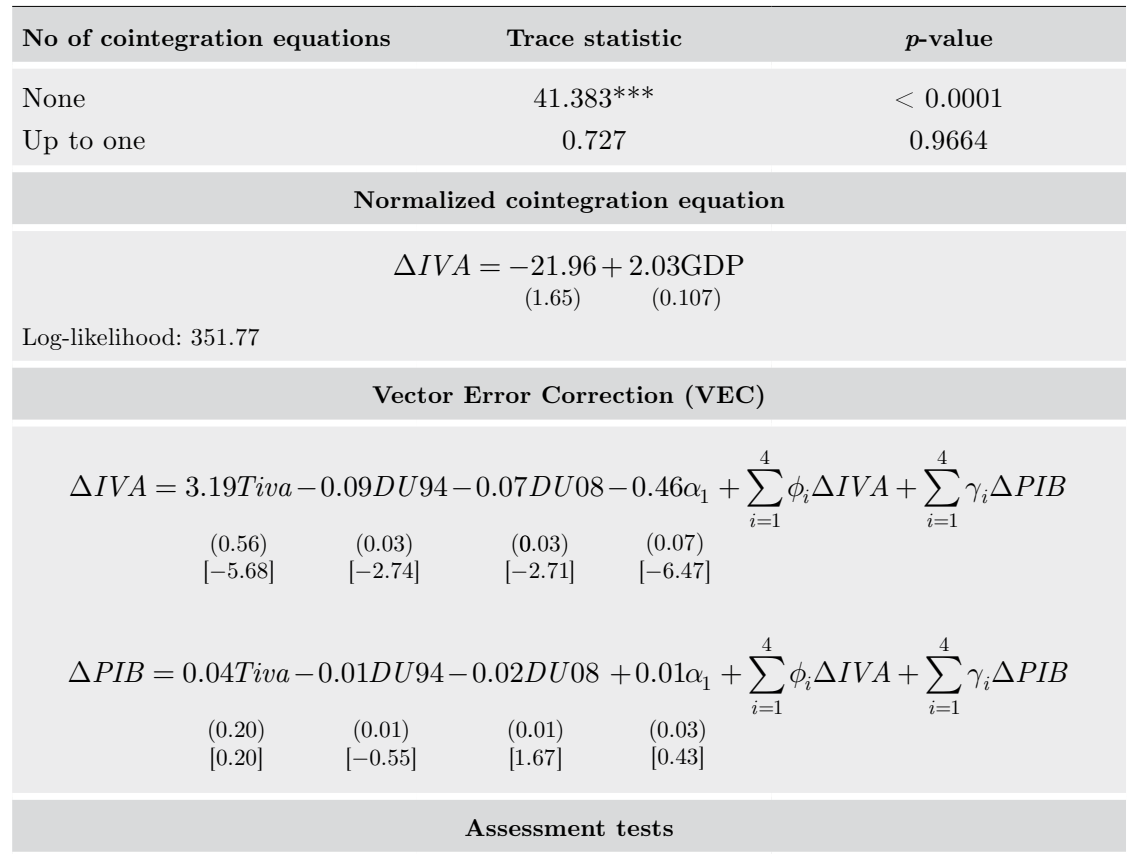

Autocorrelation test (Ljung-Box with 4 lags):

1. IVA equation: $Q=4.78$ with $p$-value $=P\left(\chi_{4 \text { d.f. }}^{2}>4.78\right)=0.31$

2. GDP equation: $Q=0.28$ with $p$-value $=P\left(\chi_{4 \text { d.f. }}^{2}>0.28\right)=0.99$

Homoscedasticity test (ARCH with 4 lags):

1. IVA equation: $L M=4.90954$ with $p$-value $=P\left(\chi_{4 \text { d.f. }}^{2}>4.90954\right)=0.296706$

2. GDP equation: $L M=1.9903$ with $p$-value $=P\left(\chi_{4 \text { d.f. }}^{2}>1.9903\right)=0.737543$

Normality test (Doornik-Hansen):

$D H=5.60065$ with $p$-value: 0.2310 (under the null it is distributed as $\chi_{4 \text { d.f. }}^{2}$ )

Source: Critical values taken from Doornik (1998).

Note: *** Significant at $1 \%$; standard error in parenthesis, $t$ statistic in brackets; $\alpha_{1}$ denotes the VEC mechanism; Tiva is the maximum IVA rate; DU94 is a dummy variable which is equal to 1 in 1994:1 hereafter and zero in other cases; DU08 is also a dummy variable equal to 1 of 2008:3 until 2009:4 and zero in other cases.

What is notable in both cases (IVA and ISR) is that it is possible to rule out the null hypothesis of no cointegration with the Johansen test in accordance with the trace statistic, ${ }^{12}$ but this can't be done when the null hypothesis proven is the existence of at least one cointegration vector. Likewise, the results obtained for each tax indicate that these

12. The same conclusion is reached with the other Johansen statistic, $\lambda_{\text {máx }}$. 
Table 7. Results of the Johansen cointegration test for the ISR

\begin{tabular}{|lcc|}
\hline No of cointegration equations & Trace statistic & $p$-value \\
\hline None & $39.17^{* * *}$ & $<0.0001$ \\
Up to one & 2.72 & 0.6390 \\
\hline
\end{tabular}

\begin{tabular}{|c|cc} 
& Normalized cointegration equation \\
& $I S R=-22.99+2.16 \mathrm{GDP}$ \\
\hline Log-likelihood: 341.29 & $(3.14) \quad(0.19)$ \\
\hline
\end{tabular}

\begin{tabular}{|c|c|c|c|}
\hline \multicolumn{4}{|c|}{ Vector Error Correction (VEC) } \\
\hline \multicolumn{4}{|c|}{$\Delta I S R=0.55 T i s r-0.16 D U 94+0.002 D U 08-0.56 \alpha_{2}$} \\
\hline $\begin{array}{l}(0.09) \\
{[6.32]}\end{array}$ & $\begin{array}{c}(0.03) \\
{[-5.60]}\end{array}$ & $\begin{array}{c}(0.03) \\
{[-0.06]}\end{array}$ & $\begin{array}{c}(0.09) \\
{[-6.54]}\end{array}$ \\
\hline \multicolumn{4}{|c|}{$\Delta P I B=0.06 T i s r-0.01 D U 94-0.01 D U 08-0.04 \alpha_{2}$} \\
\hline $\begin{array}{l}(0.03) \\
{[2.53]}\end{array}$ & $\begin{array}{l}(0.007) \\
{[-1.67]}\end{array}$ & $\begin{array}{l}(0.008) \\
{[-1.66]}\end{array}$ & $\begin{array}{c}(0.02) \\
{[-1.72]}\end{array}$ \\
\hline
\end{tabular}

\section{Assessment tests}

Autocorrelation test (Ljung-Box with 4 lags):

1. IVA equation: $Q=2.77$ with $p$-value $=P\left(\chi_{4 \text { d.f. }}^{2}>2.77\right)=0.60$

2. GDP equation: $Q=4.21$ with $p$-value $=P\left(\chi_{\text {4d.f. }}^{2}>4.21\right)=0.38$

Homoscedasticity test (ARCH with 4 lags):

1. IVA equation: $L M=7.01$ with $p$-value $=P\left(\chi_{4 \text { d.f. }}^{2}>7.01\right)=0.14$

2. GDP equation: $L M=4.47$ with $p$-value $=P\left(\chi_{4 \text { d.f. }}^{2}>4.47\right)=0.35$

Normality test (Doornik-Hansen)

$D H=7.73$ with p-value: 0.10 (under the null it is distributed as $\chi_{4 \text { d.f. }}^{2}$ )

Source: Critical values taken from Doornik (1998).

Note: *** Significant at $1 \%$; standard errors in parentheses, $t$ statistic in brackets; $\alpha_{2}$ denotes the VEC mechanism; Tisr is the maximum ISR rate for individuals; DU94 is a dummy variable equal to1 of 1994:1 hereafter and zero in other cases. DU08 is also a dummy variable equal to 1 of 2008:3 until 2009:4 and zero in other cases.

are sensitive to growth in national income: For each percentage point that this variable increases, collection of IVA and ISR increases, on average, around two percentage points (2.08 and 2.16 percentage points, respectively).

With respect to the vector error correction (VEC) model, the assessment tests exhibit good statistical behavior of the models calculated in terms of satisfying the assumptions of homoscedasticity, normality and absence of correlation. On the other hand, the results related to 
the VEC confirm the existence of a cointegration relationship between the variables for both taxes. This is inferred based on analysis of the signs of the model's stability parameters. These fulfill the following: The parameter associated with the error correction mechanism $\left(\alpha_{1}\right)$ is negative in the IVA equation (-0.46) and positive (although not significant at $5 \%$ ) in the equation of the GDP (0.01). For the ISR, the adjustment coefficient $\alpha_{2}$ shows the correct sign in the ISR equation (-0.56) but the opposite of what is expected in the GDP equation. However, the latter is not statistically significant at $5 \%$. In both cases, the error correction mechanism only applies (in the correct direction) in the tax equation, so it is possible to infer that the disequilibrium adjustment process (with respect to the long-term ratio), both for the IVA and the ISR, administered through the error correction mechanism, falls to the tax variable and not to GDP. In other words, given a short-term disequilibrium in the relationship between tax and production, the tax is adjusted to correct it, rather than production. This analysis is relevant in that it provides evidence of the condition of weak exogeneity of the GDP in relation to both taxes (see Engle et al., 1983, and Enders, 2010).

With weak exogeneity (WE) of the regressor, a very important range of potential extensions are opened for the models. Weak exogeneity is a necessary, but not sufficient, condition for strong exogeneity (StE) and for super exogeneity (SuE). With respect to StE, this also requires that there is no evidence of Grange causality of the tax to the GDP, while $\mathrm{SuE}$ requires that all instability in the marginal distribution of the GDP not affect the conditional distribution (in simple terms, the regression).

Establishing StE or SuE statistically allows, respectively, for obtaining proof that the model is useful in preparing forecasts and assessing economic policy without application of the Lucas critique. Specifically, one of the objectives of the study is to use the models calculated to develop forecasts. By inferring the weak exogeneity of the parameter associated with the GDP, all that remains is to prove that the assumptions considered do not affect the GDP in the Granger sense. The following table shows the result of applying the non-causality in the Granger sense between the GDP and the taxes. The proof is carried out both in levels and in first differences and specifying up to eight lags in the variables. 
Table 8. Results of the Granger causality test

\begin{tabular}{cccccc}
\hline & \multicolumn{2}{c}{ Levels } & & \multicolumn{2}{c}{ First differences } \\
\cline { 2 - 3 } \cline { 5 - 5 } Lags & $\boldsymbol{I} \boldsymbol{V A} \rightarrow \boldsymbol{G} \boldsymbol{D P}$ & $\boldsymbol{I S R} \rightarrow \boldsymbol{G D P}$ & & $\boldsymbol{I} \boldsymbol{V A} \rightarrow \boldsymbol{G D P}$ & $\boldsymbol{I S R} \rightarrow \boldsymbol{G D P}$ \\
\hline 1 & 2.10 & 2.01 & & $3.88^{*}$ & 0.27 \\
2 & $2.62^{*}$ & 1.41 & & 1.78 & 0.65 \\
3 & 1.95 & 0.90 & & 1.69 & 0.66 \\
4 & 1.78 & 1.32 & & $2.28^{*}$ & 0.70 \\
5 & $2.19^{*}$ & 1.49 & & 1.61 & 0.62 \\
6 & 1.53 & 1.61 & & 1.02 & 0.99 \\
7 & 1.65 & 1.78 & 0.79 & 1.24 \\
8 & 1.06 & 1.59 & 0.82 & 1.11 \\
\hline
\end{tabular}

The Granger causality test (GC) presents some problems when it is used with nonstationary variables, as in our case. Christiano and Ljungqvist (1988) presented Monte Carlo evidence which suggests that the test statistic of GC does not exhibit, under the null hypothesis, standard behavior so the statistical difference may be invalid (see also Sims et al., 1990, and Ventosa-Santaulària and Vera-Valdés, 2008). This suggests carrying out the test using the series in first differences. There is also a great deal of hesitation among researchers regarding this way of proceeding, due to the consideration that the differentiation eliminates much of the information contained in the data, rendering the test less powerful. Concerning the GC of the taxes to GDP, the tests run indicate in almost all cases that there was no evidence of this, permitting us to infer that these models constitute a valid basis for building forecasts.

In addition, the unit root tests did not detect structural breaks in any of the series either of the taxes or of GDP (see Table 4). In the absence of evidence of the existence of such breaks, it is not possible to opt either favorably or adversely to the SuE condition.

\subsection{Comparison of estimates and forecasts}

The results above, viewed from a comparative perspective for different countries - both developed as well as emerging and/or developing, see Table 9 -indicate that the revenue elasticity obtained for the ISR is greater in Mexico than in any other selected developing economies, and in relation to the developed economies, our estimate is only lower 
than that reported by Giorno et al. (1995) for the United States. In terms of the IVA, the estimated elasticity is located slightly above the average in developing countries: very similar to Bolivia, but lower than Colombia and Guatemala.

With respect to the results obtained by other studies of the Mexican case, our estimated elasticity is higher than that of CEFP (2009) and Cárdenas et al. (2008 for both the ISR and the IVA, which may be due to (i) differences between sample periods used in the cited works and the one used here, and (ii) the fact that the tax rate is not controlled for in either Cárdenas et al. (2008) or in CEFP (2009). It is worth mentioning that the Treasury Secretariat's estimates are not included because they are not published.

Table 9. Comparison of revenue elasticities in selected countries and in the Mexican economy

\begin{tabular}{|c|c|c|}
\hline & ISR & $I V A$ \\
\hline \multicolumn{3}{|c|}{ Developing and/or emerging economies } \\
\hline Colombia $^{\mathrm{a}}$ & 1.00 & 2.80 \\
\hline Chile $^{\mathrm{a}}$ & 1.13 & 1.02 \\
\hline Guatemala $^{a}$ & 1.26 & 2.26 \\
\hline Bolivia $^{a}$ & - & 1.83 \\
\hline El Salvador ${ }^{\mathrm{b}}$ & 1.49 & 1.00 \\
\hline Turkey ${ }^{\mathrm{c}}$ & 0.94 & - \\
\hline Pakistan $^{\mathrm{d}}$ & 1.21 & 1.50 \\
\hline \multicolumn{3}{|c|}{ Developed economies } \\
\hline United States ${ }^{\mathrm{e}}$ & 2.3 & - \\
\hline Japan $^{\mathrm{e}}$ & 1.4 & - \\
\hline Germany $^{\mathrm{e}}$ & 0.8 & - \\
\hline \multicolumn{3}{|c|}{ Results for the Mexican economy } \\
\hline $\begin{array}{l}\text { Mexico (Cárdenas et al., 2008) } \\
\text { 1980:1-2006:1 }\end{array}$ & 1.15 & 1.12 \\
\hline $\begin{array}{l}\text { Mexico (Capistrán, 1999) } \\
\text { 1989:1-1998:3 }\end{array}$ & 1.54 & - \\
\hline $\begin{array}{l}\text { Mexico (CEFP, 2009) } \\
\text { 1980:1-2009:2 }\end{array}$ & 1.36 & 1.88 \\
\hline \multicolumn{3}{|c|}{ Authors' calculations } \\
\hline 1990:1-2010:4 & 2.16 & 2.03 \\
\hline
\end{tabular}


As mentioned at the beginning of this paper, the Treasury Secretariat uses tax revenue elasticity to determine the expected collection amount for each tax in order to develop a forecast of collection for fiscal year 2011. Once the expected amount for each tax is obtained, the Treasury Secretariat builds monthly forecasts of the collection volume of each tax during the year through the Revenue Estimate Calendar for the Public Sector (Calendario de Estimación de Ingresos del Sector Público). ${ }^{13}$

For these forecasts the Treasury Secretariat does not use the elasticities method. Instead, it uses the annual amount obtained-and published in the Revenue Law Initiative of the Federation (ILIF) approved by Congress-applying statistical models based on exponential smoothing to obtain the seasonal factors of each tax (Treasury Secretariat, 2009) through the Holt-Winters method (in its additive and multiplicative version). To ensure, to the greatest extent possible, the validity of the comparison between the taxes forecast by the Treasury Secretariat and our forecasts, we omitted the monthly breakdown and concentrated on the annual amount in real terms. This eliminates the need to reproduce the smoothing of the Treasury Secretariat (which is, in fact, impossible, given that the Secretariat does not provide the elements needed to do that). What is necessary, however, is to transform the amounts forecast by the Treasury Secretariat into real values, which was done by using the inflation forecast that appears in the ILIF, $3 \%$ on a monthly basis as if it were compound interest.

Table 10 shows the results of the Treasury Secretariat calculations as well as those calculated here based on the VECs, prepared in millions of constant pesos with base year 2003. In both cases the 2011 macroeconomic scenario forecast in the General Criteria of Economic Policy (Criterios Generales de Política Económica, prepared by the Secretariat) of $3 \%$ expected economic growth as well as annual inflation of $3 \% .^{14}$

As shown in Table 10, our calculations are lower than the official ones for the IVA $(8.97 \%)$ and the ISR $(9.88 \%)$. The differences between them may be due to, among other things, the methodologies used to develop them. On the one hand, the Treasury Secretariat uses an exponential smoothing method which does not explicitly depend on 
the growth rate of the economy (since the method extrapolates trends) while our forecasts are intimately conditioned by said growth. If the $3 \%$ growth rate is far below what actually occurs in 2011, the forecasts derived from our VECs will also be negatively affected. Nevertheless, when calculating $5 \%$ confidence intervals of our forecasts, it is evident that the forecasts of the Treasury Secretariat are included in such intervals (see Table 10 and Figures 5 and 6).

\section{Table 10. Estimated tax collection for 2011:}

(Treasury Secretariat and authors' calculations)

\begin{tabular}{lcc|}
\hline & ISR & IVA \\
\hline & Forecast scenario & \\
\hline $\begin{array}{l}\text { Maximum rate } \\
\text { Expected growth }\end{array}$ & $30 \%$ & $16 \%$ \\
& $3 \%$ & $3 \%$ \\
\hline $\begin{array}{l}\text { Treasury Secretariat } \\
\text { (millions of constant pesos, } \\
\text { base year 2003) }\end{array}$ & Forecasts & $\$ 396,318.11$ \\
\hline $\begin{array}{l}\text { Authors' calculations } \\
\text { (millions of constant pesos, } \\
\text { base year 2003) }\end{array}$ & $\$ 491,523.03$ & \\
$95 \%$ interval & $\$ 442,950.52$ & $\$ 360,767.72$ \\
\hline \begin{tabular}{l} 
Source: Treasury Secretariat and authors' calculations. \\
\hline
\end{tabular} & {$[\$ 324,662.06-\$ 400,950.18]$} \\
\hline
\end{tabular}

\section{Figure 5. ISR collection forecast for 2011}

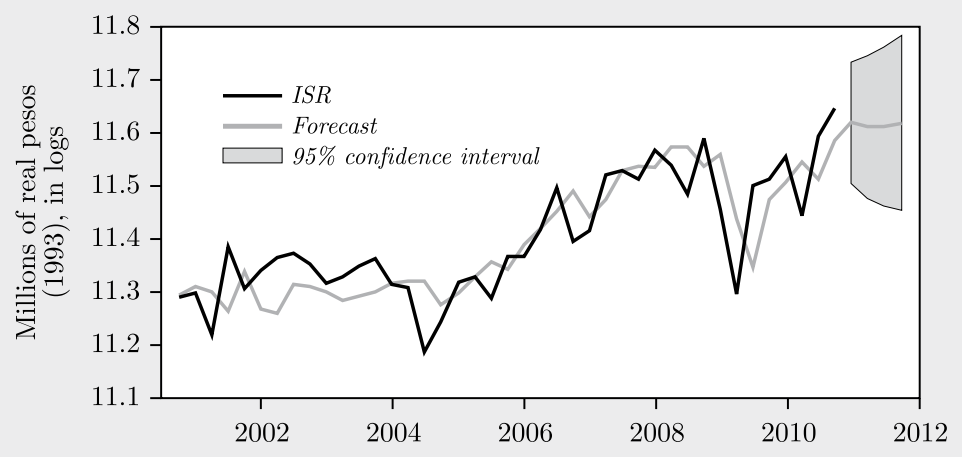


Figure 6. IVA collection forecast for 2011

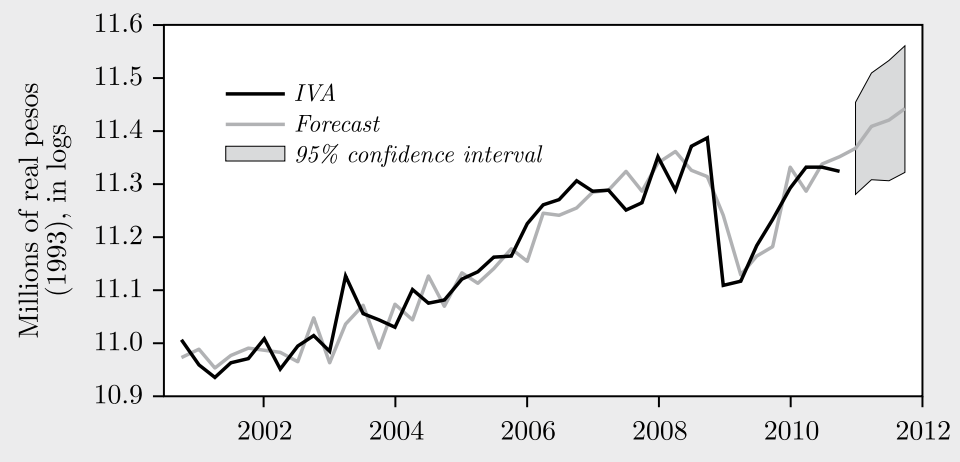

\section{ConCLUSIONS}

A tax system which is elastic to revenue reduces the uncertainty associated with tax revenue, allowing tax collection to evolve in line with growth of the national product. This paper presents calculations of the revenue elasticity of the main non-petroleum taxes in the Mexican economy: the ISR and the IVA. These two taxes comprise just over $90 \%$ of the taxes collected.

Using macroeconometric modeling supported by Johansen's methodology (1988), it was possible to establish long-term ratios between taxes and revenue. In fact, it was found that the variables belong to a cointegrated system without structural breaks (within the cointegration vector); in other words, they maintain an equilibrium relationship over the long term. Once this was done -in accordance with Granger's representation theorem- the vector error correction (VEC) model was estimated, which enabled the establishment of the error correction mechanism and furthermore, evidence of weak exogeneity of the parameter associated with revenue. This, along with evidence of Granger causality, made it possible to infer that the model constitutes a valid tool for developing forecasts.

The results obtained indicate that the taxes studied are elastic to growth in national income, with estimated revenue elasticity in both cases of around 2\% (2.16 for the ISR and 2.03 for the IVA). Also, forecasts were developed based on the estimated VEC to compare 
them to the scenario proposed by the Treasury Secretariat both in the CGPEs as well as the Revenue Law (ILIF) approved in 2011. This is particularly valuable once the conditions of weak and strong exogeneity were proven in the model used to create the forecasts. 


\section{REFERENCES}

Antón-Sarabia, A. (2005), "Average effective tax rates in Mexico," Economía Mexicana 14(2): 185-215.

Bilquees, F. (2004), "Elasticity and bouyancy of the tax system in Pakistan," The Pakistan Development Review 43(1): 73-93.

Capistrán, C. (1999), "Elasticidad ingreso del ISR: una aplicación de la metodología general a particular en econometría," Gaceta de Economía 10: 5-57.

Cárdenas, O., D. Ventosa-Santaulària, and M. Gómez (2008), "Elasticidad ingreso de los impuestos federales en México: Efectos sobre la Recaudación Federal Participable," El Trimestre Económico 80: 355-85.

Centro de Estudios de las Finanzas Públicas del H. Congreso de la Unión (2009a), "La elasticidad del ISR y del IVA respecto al producto interno bruto," Documento de Trabajo, mcnotacefp 055. Available at http://www.cefp.gob.mx

. (2009b), "Tasa efectiva promedio de los impuestos al consumo en México," Nota Técnica, notacefp 080. Available at http://www.cefp.gob.mx

. (2010), Diagnóstico del Sistema Fiscal Mexicano. Available at http://www. cefp.gob.mx

. (2010), Nota Informativa: Reforma Fiscal 2010. Available at http://www. cefp.gob.mx

Christiano, L.J. and L. Ljungqvist (1988), "Money does Granger-cause output in the bivariate money-output relation?," Journal of Monetary Economics $22(2): 217-35$.

Doornik, J.A. (1998), "Approximations to the asymptotic distribution of cointegration tests," Journal of Economic Surveys 12: 573-93.

Enders, W. (2010), Applied Econometric Time Series, $3^{\text {rd }}$ Edition, Wiley.

Engle, R.F. and C. Granger (1987), "Cointegration and error correction: Representation, estimation and testing," Econometrica 55: 251-76.

Engle, R.F, D.F. Hendry, and J.F. Richard (1983), "Exogeneity," Econometrica 51(2): $277-304$.

Fuentes, J. and M. Tobar (2004), "La política fiscal como herramienta de ajuste cíclico en El Salvador," Departamento de Investigación Económica y Financiera, Banco Central de la Reserva de El Salvador. Available at http://www.cemla.org

Giorno C., P. Richardson, P. Roseveare, and P. van Der Nord (1995), "Potential output, output gaps, and structural budget balances," OECD Economic Studies 24: 167-209.

Gregory, A. and B. Hansen (1996), "Residual-based tests for cointegration in models with regime shitfs," Journal of Econometrics 70: 99-126.

Groves, H. and H. Khan (1952), "The stability of state local and local tax yield," American Economic Review 42: 87-102. 
Johansen, S. (1988), "Statistical analysis of cointegration vectors," Journal of Economic Dynamics and Control 12: 231-54.

Kapetanios, G. (2005), "Unit root tensting against the alternative hypothesis of up to m structural breaks," Journal of Time Series Analysis 26(1): 123-33.

Kustepeli, Y. and O. Sapci (2006), "Personal income tax elasticity in Turkey: 1975-2005," Discussion Paper Series No. 06/01, Departament of Economics, Dokuz Eylül University.

OECD (2010), Main Economic Indicators, Organisation for Economic Co-operation and Development: Paris, France

Secretaría de Hacienda y Crédito Público (2010), "Acuerdo por el que se da a conocer el Calendario Mensual de la Estimación de los Ingresos contenidos en el Artículo $1^{\mathrm{O}}$ de la Ley de Ingresos de la Federación para el Ejercicio Fiscal de 2011 y la Metodología utilizada para realizar dicha Estimacion," Diario Oficial de la Federación (DOF), Miércoles 17 de Diciembre de 2010.

. (2010), "Documento Relativo al Cumplimiento de las Disposiciones Contenidas en el Artículo 42, Fracción I, de la Ley Federal de Presupuesto y Responsabilidad Hacendaria," Secretaría de Hacienda y Crédito Público. Available at http://shcp.gob.mx

Sims, C.A., J.H. Stock, and M.W. Watson (1990), "Inference in linear time series models with some unit roots," Econometrica 58(1): 113-44.

Stock, M. and J. Watson (1988), "Testing for common trends," Journal of the American Statistical Association 83: 1097-107.

Ventosa-Santaulària, D. and M. Gómez-Zaldívar (2010), "Testing for a deterministic trend when there is evidence of unit root," Journal of Time Series Econometrics 2(2): Article 3.

Ventosa-Santaulària, D. and J.E. Vera-Valdés (2008), "Granger-causality in the presence of structural breaks," Economics Bulletin 3(61): 1-14.

Zivot, E. and D. Andrews (1992), "Further evidence on the great crash, the oilprice shock, and the unit-root hypothesis," Journal of Business \& Economic Statistics 10(3): 251-70. 


\section{APPENDIX A. ORDER OF THE ESTIMATED VECS}

\section{Through information criteria}

AIC: Akaike Information Criterion; BIC: Bayesian information criterion (Schwarz); HQC: Hannan-Quinn Criterion

Table A1. ISR

\begin{tabular}{cccc}
\hline Lag & AIC & BIC & HQC \\
\hline 1 & $-7.968^{*}$ & $-7.595^{*}$ & $-7.819^{*}$ \\
2 & -7.898 & -7.400 & -7.700 \\
3 & -7.865 & -7.242 & -7.610 \\
4 & -7.875 & -7.128 & -7.577 \\
5 & -7.921 & -7.050 & -7.574 \\
6 & -7.831 & -6.835 & -7.434 \\
7 & -7.829 & -6.708 & -7.380 \\
8 & -7.845 & -6.600 & -7.348 \\
\hline
\end{tabular}

For the ISR, the three criteria coincide in that only one lag must be specified.

Table A2. IVA

\begin{tabular}{|cccc|}
\hline Lag & AIC & BIC & HQC \\
\hline 1 & -8.383 & $-8.015^{*}$ & $-8.236^{*}$ \\
2 & -8.375 & -7.885 & -8.180 \\
3 & -8.378 & -7.765 & -8.133 \\
4 & -8.422 & -7.68 & -8.128 \\
5 & $-8.503^{*}$ & -7.645 & -8.160 \\
6 & -8.446 & -7.464 & -8.053 \\
7 & -8.354 & -7.250 & -7.913 \\
8 & -8.334 & -7.108 & -7.844 \\
\hline
\end{tabular}

For the IVA, BIC and HQC criteria suggest a specification with a single lag; the AIC suggests 5 lags. Given these two options, first a 
$V E C(1)$ was chosen, but this model does not yield residuals satisfying the assumptions. Thus, the decision was made to use $V E C(5)$, because its residuals satisfy the assumptions of homoscedasticity, normality and independence.

\section{APPENDIX B. VAlues USED IN PREPARING THE FORECASTS:}

Table B1. GDP: 3\% growth rate

\begin{tabular}{|cc|}
\hline Quarter & LGDP \\
\hline $2011 / 01$ & 16.0316 \\
$2011 / 02$ & 16.0335 \\
$2011 / 03$ & 16.0342 \\
$2011 / 04$ & 16.0356 \\
\hline
\end{tabular}

Table B2. CPI: $3 \%$ growth rate

\begin{tabular}{|cc|}
\hline Month & CPI (base year 2003) \\
\hline 2011.01 & 138.38 \\
2011.02 & 138.72 \\
2011.03 & 139.06 \\
2011.04 & 139.41 \\
2011.05 & 139.75 \\
2011.06 & 140.09 \\
2011.07 & 140.44 \\
2011.08 & 140.79 \\
2011.09 & 141.13 \\
2011.10 & 141.48 \\
2011.11 & 141.83 \\
2011.12 & 142.18 \\
\hline
\end{tabular}

